\title{
Commodification of Labor and the Morphogenesis of Exploitative Structures in Television Program Production
}

\author{
Cosmas Gatot Haryono \\ Universitas Bunda Mulia \\ Jakarta, Indonesia \\ cgharyono@gmail.com
}

\begin{abstract}
When industrialization penetrated television media, the logic of capitalism (suppressing spending to achieve the greatest possible profit) becomes the basic idea of television management. Than rating and share become the central of television management and determined whether a broadcast program feasible. On the other side, workers are assumed to be merely a means of production classified by their skills and ability to execute a policy. Unfortunately, the television workers do not realize it. They often look very enjoy and feel in the special room, which full of luxury. This research found that exploitative work structure are created through a morphogenesis process, where structure is reproduced through corporate culture. As an agent, television labor powerless to make significant changes. They are trapped in that exploitative structures because of their inability to overhaul the structures. Otherwise, the structures that have entrenched shape the way and view of the worker mindset, including about their work.
\end{abstract}

Keywords-Labor Commodification, Exploitative Structure, Morphogenesis, Television Industry

\section{INTRODUCTION}

Nowadays conglomeration has penetrated into the world of media (including television) in Indonesia and ultimately leads to the fulfillment of the "economic interest" of capital owners, translated by rating placement as central to all broadcasting management. Ratings are transformed into a feasibility tool for broadcast program justification. Ratings determine and "dictate" the feasibility of a broadcast program to be maintained or otherwise, discontinued. As a result media managers are caught in the fetish (commodity fetishism) trends, in which media actors "deify" certain broadcast programs and whatever they will do to maintain the rating of the program, including ignoring or even hiding exploitation of the content of broadcasters, audiences, and workers involved in the production, distribution and consumption of the broadcast program.

So it is not surprising that there are models of duplication and epigonism (pengekoran) broadcast programs conducted by private television in Indonesia because other television broadcast programs get a high rating [1]. There is no more "shame" to follow other TV programs to get existing and cakes. Also rampant mass broadcast programming. When a television program has proved successful in the market, it is usually exploited to commercial exhaustion and also replicated by other station as well.The consequence is the occurrence of commercialization and commodification on all media industry products [2].

The direct impact is television management often exploit labours. They are conditionned to work hard even never think about time and their basic right as labours for rating. In the name of professionalism and work assertion, they often works harder than normally without additional salary. They also are charged to be multitasking. Unfortunately, almost television worker enjoy it without question. Almost all television labours unrealize that they are trapped in false consciousness. They exactly seem very enjoy and feel like work at special industry that full of luxury facilities. This is just one example in the production area, yet in other parts in a company. So many things commodified, but never unnoticed by the workers themselves.

\section{RESEARCH METHOD}

This article is a report of qualitative research that explores the commodification of television labor in Indonesia. As qualitative research, author use inductive way of thinking, the way of thinking which departed from the things that are special (empirical evidence) towards matters of a general nature (the concept level). The research examines exploitation of labor and morphogenesis structure of television labors. This research use Mosco's political economic theory in critical paradigm.

\section{A. Political Economy of Media (Vincent Mosco)}

The theory of political economy focus on: how the media constructed and controlled, offers empirical investigations regarding the financial media, and find the relationship between media content production process and the financial media [3]. Mass media viewed as who the ruler of sources of mass media production, who holds the distribution chain of mass media, who create the consumption pattern over the mass media and other commodities as the effects of media work.

Mosco said that the political economy is a study of social relations, especially relations of power, that is contribute to the production, distribution, and consumption of resources, 
including communication resources. The political economy also defined as the study of control and defense of social life [4]. In the mass media institutions, it regarded as an economic system that is closely linked to the political system. Because It's focus on the relationship between economic and political structures, the dynamics of the media industry and media ideology itself (the ownership, control and operational strength of the media's market).

Mosco emphasizes the four important characters of political economy of media, namely: social change and history, social totality, moral philosophy and praxis [4]. Social change and history refers to the change or even revolution capitalism huge and terrible. Social totality refers to a wide spectrum of economic issues of media politics. Moral philosophy refers to the orientation of the political economy of the media is not only limited to the question "what", but more than that "what it should be". While praxis see knowledge as a product of interaction and dialogue between theory and praxis continuously.

There are three entrances to explain the concept of the political economy of communication, that is commodification, spatialization and structuration [4]. First, commodification related to the transformation of use value into exchange value, which change anything into a commodity or merchandise as a means to gain an advantage. Commodification itself consists of three types, namely the commodification of content or the content, audience and labours commodification. Commodification of content is the formation of the exchange rate which describes the overall practice of social relations. News media or content seen as a commodity to increase the number of audience or circulation. Commodification of audiences see the number of audience or circulation as a commodity that can be sold to advertisers. And the commodification of labor are used to improve the flexibility and control for workers. Further, adding value of labours transformed be something that participate in the process of production of goods and services.

Second, spatialization is a process to overcome the limitations of time and space in social life. Spatialization, with regard to the extent in which the media is able to present its products in front of the reader within the limits of space and time. Then the media institutional structures determine its role in the network and the speed of delivery of media products in front of audiences.

Third, structuration is the process of forming social structure through the agent. Structuration deals with the relation between the idea of community agencies, social processes and social practices in the structural analysis. Structuration can be described as a process in which the social structure enforced by social agents, and even each part of the structure is able to do to serve the other. The end result of structuration is a series of social relationships and power be organized between class, gender, race and social movements that related each another.

\section{B. The Commodification of Labours}

Mosco explains that the process of commodification closely related with the product, while the production process is closely related to the function of labours or workers [4]. Practically, when the process of commodification is running, the actual workers themselves have turned into commodities and has been commodified by the owners of capital.

In this perspective, labor not only be regarded as a mere employee but an asset that can be enabled in various types of functions to move the media company. Labors are driving activities not only in production, but also distribution. Utilization of energy and their thoughts in an optimal way to construct their thoughts about how to please when it works in a mass media institution, although the wages are not fair.

Commodification employees or labors are working in the transformation processes of capitalism, where the skills or expertise and working hours of the workers looked as commodities and are rewarded in salary. In the commodification of labor, there are two processes that can be considered. First, the commodification of labor is done by using a communication system and technology to improve the control of the labor force and ultimately the whole process mengomodifikasi use of labor, including those in the communications industry. Secondly, political economy describes a dual process that when the workers in the proceess of acomodation activities, at the same time they also commodified.

\section{Work, Labor and Alienation}

In Indonesia, said "buruh" has a "derogatory" connotation rather than using the word of "karyawan", "pekerja", atau "tenaga kerja". "Buruh" or labor are always stereotyped as hardworking, abusive, and tend to use more energy or muscle than their brains. In fact, the four terms have the same meaning. Adam Smith with his classical political economy sees that labor is always characterized by a division of labor that is a demand for welfare. For Smith, workers (who are poor people) and financiers (rich) are related to one another: they are God-given people as assumed in Christian philosophy, but necessary for progress [5]. The idea of the nature of hard work and poverty is something God gives; while class relations are understood as a social relationship. This relationship is, however, deemed necessary for some progress. The potential for abuse is not seen as a historical potential made possible by the development of productive forces

In contrast, Karl Marx criticized it. Marx even laid the historical potential of workers and class relations as a crucial point in his critics to capitalism. For him, the overall nature of man is always related to work. By analogizing work as a bee making nest, Marx connects between work and human nature [6]. First, which distinguishes man from animals is the fact that human labor embodies something in reality, which previously existed only in the imagination. In the work, man creates external objects outside his mind which later known as the term objectivication. Second, the work of man is always material to meet the needs of a material nature as well. At this stage there are forms of essential relationships between human needs and the material objects that become the necessities of life. Third, while working, humans undergo a transformation of human nature. When man works, he not only changes nature, but also changes himself, including the needs, consciousness, and human nature.

In capitalism, the worker sells his labor as a commodity to the capitalist and therefore operates on one part of the day 
(working hours necessary) to create "the value of his labor power, the value of him as a means of subsystem" (Marx $1867 \mathrm{c}, 324$; the other part of the day is not "for itself" but for the capitalists. In this period, he "creates more value" (ibid., 325). Marx refers to this passage from "surplus labor, and labor expended over time it is given the name of surplus labor "(ibid., 325)

The workforce never owns its own means of production, has no result of its production and in its production process is forced to work in a certain part of a day without payment (eg to do labor surplus) so that more value is created transformed into capital. Treating labor as a commodity also provides monetary benefits for workers, ie money or salary. But the tendency of labor is objectified and traded in the market. Workers no longer work as a form of expression of their purpose in life. No more objectivation. On the contrary, workers work on the basis of the capitalist goal of paying and hiring it [6]. this condition reduces work to be a means to earn money only; no longer seen as a means of expressing the capabilities and potentials of its humanity.

Marx calls this condition a worker alienation (alienation). Wherein the inherent relationship between work and human nature that should be intertwined is precisely diverted by capitalism [7]. Capitalists use and treat their workers and means of production as end products and workers are forced to sell their working time to capitalists so that they can survive [6]. Finally, humans only feel active in their animal functions, while in the process of working, they no longer feel themselves to be nothing but animals (idem, 37).

\section{Morphogenesis Structure}

The concept of morphogenesis consists of two elements, namely "morfo" and "genesis" [8]. The first element ("morfo") implies that the so-called society is not a form of recognition made by the state, so that society is dynamic or undergoing change. While the second element ("genesis") implies that society is a settlement formed from and by agents derived from the consequences of their activities, whether desired or not.

Archer morphogenesis analysis works through three stages. First, the structural conditioning stage that refers to the preceding (pre-existing) structure that conditions something but does not determine (to condition but not determine). Secondly, Socio-cultural interaction, which arises from action oriented to the realization of interests and needs derived from the agent and leads to change. Third, structural elaboration or modification, a change in the relationship between the parts within a social system.

Archer [9] argues that the relations of agents and structures can not only be seen limited in the perspective of domination, but furthermore also saw in the perspective of the expansion of structures generated by the relationship of structure and agent. The process of interaction between structure and agent not only creates a structural change of a system, but can result in structural expansion both theoretically and methodologically.

This dualism analysis offers placing structures and agents separately because the structures and agents are two different things and are a separate phenomenon. In the context of their mutual relations, temporality (the question of time) is seen as the main aspect. The structure is always present preceding actions which in turn lead to structural reproduction or elaboration and produce continuous cycle continuity. This process occurs over time and produces an endless "cycle" of structural changes, action changes, interaction and structural extension.

Morphogensis put culture (culture) as a key word in an agency-structure relationship. For Archer, culture is an inherent factor in structure-agent relations. The interactions and actions of the agents create structures that also react and change with the actions and interactions of agents. That change will always create a structural extension.

\section{RESUlt AND DISCUSSION}

\section{A. Labour Commodification: Exploitation on Professionalism And Time}

For television in Indonesia it must be admitted that the "rating" determines whether or not a broadcasting program is to be maintained or otherwise terminated. Practically, the "rating" dictates the entire content of the television broadcast and brings the media manager to the tendency of fetish (commodity fetishism), a trend in which media actors "disguise" certain broadcast programs because it is already high rating so anything will be done to maintain the rating the program.

"Kalau di Trans7, polanya sebenarnya program itu bukan lagi program itu bukan idealisme si pembuat. tapi lebih melihat pasar. Kalau dulu kita bikin nasi goreng, kita juga yang makan nasi goreng itu. Kalau sekarang kita mesti tahu, penonton maunya apa sih..? kita sediain... penonton mau makan apa sih..? kalau penonton maunya makan indomie kita masakin indomie, kalau mau nasi goreng ya kita masakin nasi goreng. nah mau ngga mau seperti itu.. ya karena barometernya ya share itu... karena kalau lihat dari share, grafik by minute nya ketahuan penonton itu suka dengan adegan apa sih... suka dengan item apa sih... suka dengan dengan apa gitu... jadi kita bisa create sesuai dengan kebutuhan penonton.." (YE, Produser Trans7)

Furthermore, the rating "kills" the worker's idealism in work. The main consideration of program production is not about the values of idealism, but what the audience likes and likes. Although a quality program is mediocre or even "ugly" but if it has many fans will continue to be produced and massify because it invites many advertisers.

Mainstreaming this rating ultimately leads the media to the practice of worker commodification. In the observations that researchers did in Trans7, researchers found that one form of worker commodification was done through a less formalized work procedure. The approach of friendship is more advanced so that conflict and rejection can be avoided. Management always see the crew as a creative team that can not be pressed. They realize that the more pressed the workers are the more difficult to control. In addition, positioning employees as creative workers actually also "cradles" employees or crew to feel not as laborers or hired workers, instead becoming a 
group of creative people who seem to be given "space of freedom" for the creation of a high-ranking program.

"Karena kita ini kan kerja tim... kalau menggunakan model yang terlalu kaku atau sakleg atau terlalu arogan kan berpengaruh kan... karena kerja yang butuh kreativitas itu ngga bisa ditekan... kalau gw memahaminya seperti itu... kerja kreatif itu ngga bisa ditekan... kalau dipaksapun sampai kapanpun ngga akan pernah bisa produktif... tapi dengan dikasih kebebasan ...” (YE, Produser Trans7).

Although they are creative workers who are given a lot of freedom, in the production process, television media workers are never separated from work schedule arrangements that sometimes exceed their human capacity as labor commodities are reproduced through the process of absolute exploitation (extending the work day) and relative exploitation (intensification work processes) that deepen the extraction of surplus value [4]. There are several television media that apply sift work system by dividing a day ( 24 hours) into two work shifts. So in one sift a media worker must work 12 hours a day. Within 12 hours of work and even then, rest, eating, and worship are limited to one hour. In many cases, the working hours are continuous, including Saturday and Sunday. In the end the capitalist system managed to alienate the worker from his work and his co-workers [6].

"Ya sistem kerja kita dibagi kedalam dua periode... 20 hari di luar jakarta (produksi) dan 10 hari di jakarta (pasca produksi dan pra produksi). Selama di luar jakarta kita memproduksi acara untuk keperluan acara sebulan. Setelah selesai kita "jahit" di jakarta selama 10 hari. Nah..10 hari itu kita gunakan untuk riset, editing, persiapan-persiapan dan macem-macem lah." (YE, Produser Trans7).

It turns out the workers take for granted what is already scheduled. They see that it is an unavoidable risk of job choice. Even they are willing to sacrifice a lot of time for the company, although not get more compensation in addition to honorarium service out of town.

"Ya diikuti saja lah pak... mau apa lagi.. mau kerja diTV manapun juga seperti ini. Kan sudah resiko kerja di tim produksi TV kan pak”. (SJ, Kameraman)

In the television media also do not recognize over time or overtime hours. Even in many cases, in the work agreement letter clause the absence of over time is also mentioned. They must be ready to work beyond the supposed clock without any compensation. In addition, media workers should also be ready to stand by on call at any time in case of things that the company needs. This alertness on the one hand ensures the continuity of broadcasts from television stations, but on the other hand makes the media workers can never get out of work because at all times have to give up time for the company. They should also be ready to be assigned anywhere, including areas of conflict, disaster, and other dangerous areas.
Irregular work system, division of labor that is not in accordance with the job description, the absence of melting time, outsourching system, standby on call system, etc. are real examples of forms of commodification of workers by television media in Indonesia. This is because the logic of the Indonesian television media industry has practically used capitalist logic, in which they put workers not only as workers, but assets that can be functioned into various types of functions to drive media companies. Workers are the main driving force not only in production, but also in distribution [4]. Included is the optimal use of their mind and energy by constructing their minds on how fun it is to work in a mass media institution, even with unfair pay.

\section{B. Morfogenesis of Exploitative Struktur in Television}

Capitalism is always filled with a mental attitude that always seeks to profit rationally and systematically. Its presence in the industry produces a rationally managed enterprise model [10] Through this rational and systematic governance, control and management seem more transparent and full of "comfort". Thus, the accumulation of capital objectives in the form of profit does not seem to burden or disrupt the performance of the company.

The "comfortable" conditions created by the investors become one of the characteristics raised in the management of television in Indonesia. This "comfortable" state becomes a kind of false consciousness "injected" into the television workers. From the observations that researchers have done in Trans7, there are generally common ways of managing television media in Indonesia to build a false awareness in media workers, among others: first, the television worker is the work of professionals who are different from the workers in general. They have special skills and are always close to the sources of information. So the jargon of media workers as professional jobs that require the ability to think and high skills to be the main demands [11].

Second, the television media industry is a prestigious industry. So joining the television media industry is synonymous with the achievement of life. In new employee recruitment practices, employee induction plays an important role in indoctrinating these values. Usually done by showing the superiority of corporate values and vision- mission to be achieved during the employee. Third, the use of uniform as identity and grow spirit de corp. By using a uniform, there will be a strong sense of togetherness and cultivate a sense of kinship and solidarity [12]. By joining in one of the television media then someone by itself joined in the "big family" of the television media. In the "extended family" there is usually not a difficult "conqueror" children. Then the potential conflicts that harm the company can be reduced.

Fourth, by working in the television media industry, then there is the possibility of our face appears on the screen, though not all employees. The opportunity to become famous and become "celebrities" is very wide open. Some departments in the television industry make it possible, for example news department (being a reporter and newscaster), promo department (being a promo artist promo program), and production department. Fifth, the sense of kinship created by media owners in the work atmosphere (kinship management) is very important in pushing media workers trapped in a pool of false consciousness. Some media manage media with a 
familial model that indirectly "silences" differences and disagreements. Models like this make the organization's corporate atmosphere that is formed is a kinship organization so that the boundaries between workers and owners to be blurred. Than, the tendency to go against corporate management becomes very small as more emerging is empathetic communication in media workers. The media worker always positioned himself on the side who might be opposed to himself and feel the emotions of others [13]. It makes them seem easy to understand each other.

In the context of Archer's morphogenesis, the acceptance of workers in these working conditions as comfortably can be analyzed through three stages. First, the structural conditioning stage that refers to the preceding (pre-existing) structure that conditions something but does not determine (to condition but not determine). At this stage, workers begin to enter into new work systems. Practically he must understand the conditions that exist in his new environment. This phase is essentially a self-conditioning phase of the worker with the new environment and all its value systems and visions.

In this stage it is usually utilized by the management to do "brain wash" to new workers so quickly understand the values and corporate culture. In the television industry, this phase is done on new workers by instilling the company's important values. Usually done by playing big narratives about life in the television industry.

\begin{abstract}
"Sebelum masuk ke tim... di awal gabung Trans7, semua karyawan masuk dalam kelas induksi. Ada kelas yang namanya $A$ to $Z$ Journalism.... Di situ akan ditanya, apakah jurnalistik sudah menjadi panggilan hidupmu? Tentunya dari filosofi-nya. Tentu tidak harus dijawab saat itu juga... Jadi akan ditanyakan terlebih dahulu, sehingga anak-anak baru ini bisa mengukur diri apakah pekerjaan ini menjadi panggilan diri mereka atau tidak. Atau hanya sekedar mencari steping stone untuk tahap berikutnya." (GP. Produser Trans7)
\end{abstract}

Usually induction is also done by comparing with the fact outside that looking for work in Indonesia is difficult, unemployment is still a lot, and others. This is a form of cultivating the value of fortune earned employees for joining the company. The decision to join the television industry is the right step and it does not need to be re-docked "its hometown".

"Di luar sana masih banyak pengangguran yang tidak beruntung seperti saya... mereka masih harus mencari pekerjaan yang layak dan susah payah mencari sumber keuangan bagi keluarga mereka... saya lebih beruntung lah mas... jadi harus disyukuri sudah gabung di sini... umur saya sudah tua (43 tahun), anak sudah dua ya mau apa lagi toh... selama saya masih kuat ya saya tetap lah jalani pekerjaan ini wong ngga berat-berat amat kok..." (Moh. SA, Production Assistant)

The Second Phase, Socio-cultural interaction, arises from action oriented towards the realization of interests and needs derived from the agent and leads to change. This phase is traversed by interacting with various parties in a structure. There is usually a complex exchange, which creates no structural change from a system, but also an end product of structural extension [6].

In this phase, the agent interprets what his idealism is with what he wants and needs. If you find a fact that is not in accordance with the rules, the end will be compared with the facts of his needs. For example working conditions that force work in a long time (12 hours working hours), it will appear disregarded his desire and more concerned with his needs. Workers will further highlight the aspect of his needs than his desire.

In many cases, the worker must ultimately adapt to the work patterns of the broadcast program he voluntarily participates in because he or she feels as a new person or does not need to make changes. Often workers actually position themselves as a part that must adapt because however out there looking for work is not easy.
"Ya klo itu sebenarnya kare konsekuensi ja... karena setiap program kan beda pola kerjanya. Mereka sudah harus bisa mengikuti pola kerja masing- masing program. Kalo misalnya memang harus tiap hari masuk ya itu bagian konekuensi dari program. Tapi kalau memang bisa libur tiap sabtu-minggu ya itu dimanfaatin aja... ya itu tergantung apakah mereka siap untuk ditempatkan di program itu atau ngga... ya mereka harusnya siap dengan kondisi kerja di progran itu. (YE. Produser Trans7)

In the case of the rights struggle as a worker, some television workers are caught in a false self-perception. They consider themselves intellectuals and professionals to make them often feel like they are at a higher caste than the workers. Thus, unions are not part of their professional lives that need to be followed. Some even assume their participation in the union will degrade their social status as professionals.

\section{"Buat apa ikut-ikutan bikin serikat pekerja kalau ujung-ujungnya capek doang... lagian kita kan bukan buruh yang kerjaannya demo tiap hari... kita kan pekerja profesional ya.. di penyiaran jadi ngga perlu lah seperti mereka..." (MSA, Production Assistent)}

Among media workers in Indonesia, issues relating to the establishment of unions are relatively new and difficult to do. While some media workers, especially journalists, have had much direct contact with the issues of trade union struggle through their coverage, establishing trade unions in the media environment is extremely difficult. The Indonesian Journalists Association (AJI Indonesia) and the Independent Media Union Federation (FSPM) say that of the approximately 2,000 media companies in Indonesia there are only about 40 unions formed. However, of the 40 unions, only $24 \mathrm{SP}$ are still active, while others are inactive [14]. Of course this is an irony. Media workers seem "reluctant" to establish joint struggles to fight for their own rights as workers. Some of them take refuge in their "professional" predicate, while others tend to be cautious because of the difficulty of finding other suitable work and other considerations related to household needs.

The third phase, structural elaboration or modification, is a change in the relationship between the parts within a social system. This phase of the agency performs structural 
elaboration or modification of the existing structure. Modifications made are usually not drastically structural changes, but changes that are elaborative or change the structure in a minor way according to their needs.

This phase is usually more marked by the customers of corporate values or corporate culture that is considered to have a higher value. For example how to live solidarity and sense of belonging through uniformity of value. For example the use of uniform as identity and grow spirit de corp. Uniform use, there will be a strong sense of togetherness and foster a sense of kinship and solidarity [12]. By joining in one of the television media then someone by itself joined in the "big family" of the television media. In the "extended family" there is usually not a difficult "conqueror" children. Then the potential conflicts that harm the company can be reduced.

\section{"Seragam ini menyatukan kami... jadi kami tahu identitas kami... siapa dia dan bahkan posisi apa dia kadang kelihatan dari seragamnya... selin itu... keren juga loh... “ (MSA, Production Assistant)}

Finally such workers have been in comfort condition and feel the need to maintain that comfort. Thus there is no urgency to exploit all forms of exploitation that occurred on him. There is a new awareness that the work culture in the television industry is like that. That's what makes them different from other companies. This apparent "comfort" seems to be reproduced and becomes a mandatory culture in the television industry.

Then what happens then arises those habits that are perpetuated and even expanded or cultivated. The culture then becomes a demand for them to join work on television. A person who is affiliated with television will usually be briefed on the risks of work that require many sacrifices of this kind. They will also be given equal sanctions if they refuse, complain or do not perform their duties.

Institutionally, the company instills these values and must be held firm as a working principle. For example, do not often complain about being unprofessional, well behaved (watch attitude), and hone skills every time. All that becomes a guarantee to be successful in working because it reflects the values of professionalism. If the values of professionalism are violated, then negative stamps will appear.

\section{CONCLUSION}

One way that can be done to increase profits is to increase the exploitation of workers by commodification by instilling a false consciousness into the minds of media workers. In the television industry in Indonesia, the commodification of workers is done covertly through big narratives or credos built by television management. Worker's commodification runs without coercion because it is built in a false consciousness naturally. Television media workers themselves take for granted all the exploitation and commodification it receives because the exploitation structure undergoes morphogenesis so it is not perceived as a pressure. Instead, the structure of exploitation is accepted as a culture of work that is needed and often later expanded.

\section{REFERENCES}

[1] Lukmantoro, Triyono, 2008, Rating Televisi: Komodifikasi Estetika dan Standarisasi Selera, dalam Diskursus Relasi Masyarakat, Bisnis dam Media, Yogyakarta: FISIP Atmajaya, hal. 59-83

[2] Kellner, Douglas, 1995, Media Culture: Culture Studies, Identity and politics Between the Momdern And the Postmodern, London: Routledge

[3] Baran, S. J. \& Davis, D. K. (2010). Teori Komunkasi Massa: Dasar, Pergolakan dan Masa Depan, Jakarta: Salemba Humanika, P. 263

[4] Mosco, Vincent, 1996, The Political Economy of Communication: Rethinking and Renewal, London: Sage Publications, Inc

[5] Fuchs, Christian, 2014, Digital Labor And Karl Marx, New York: Routledge, p. 24

[6] Ritzer, George \& Goodman, Douglas J., 2004, Sociological Theory Karl Marx and Varieties of Ne-Marxian Theory, New York: McGrawHill

[7] Cooper, Dereck, On the Concept of Alienation, International Journal of Contemporary Sociology 28: 1-26

[8] Sibeon, Roger, 2004, Rethinking Social Theory, Sage Publication, p. 97.

[9] Archer, Margareth, 1988, Culture and Agency: The Place of Culture in Social Theory, Cambridge: Cambridge University Press

[10] Weber, Max, 1905, The Protestant Ethic andthe Spirit of Capitalism, London: Routledge.

[11] Wibowo, Fred 1997, Dasar-Dasar Produksi Program Televisi, Jakarta: Grasindo

[12] Fussell, Paul, 2003, Why We Are, What We Wear, New York: Houghton Mifflin Company

[13] Ivancevich \& Matteson, 2002, Organizational Behavior and Management, USA; McGraw-Hill

[14] https://aji.or.id/read/berita/475/fspm-independen-dan-aji-serukanpentingnya-serikat-pekerja-media.html 